\title{
Antiviral Agent
}

National Cancer Institute

\section{Source}

National Cancer Institute. Antiviral Agent. NCI Thesaurus. Code C281.

Any agent that can treat or prevent viral infections by interfering with the viral replication cycle. 